\title{
Evaluasi Tata Kelola Teknologi Informasi Dinas Pariwisata dan Kebudayaan Kota Ambon Menggunakan Framework Cobit 5.0 pada Domain Monitor, Evaluate And Asses (MEA)
}

\author{
Juan Adithya Imanuel Belegur ${ }^{1,}$ Chris Rudianto ${ }^{2}$, Melkior N. N. Sitokdana ${ }^{3}$ \\ Fakultas Teknologi Informasi, Universitas Kristen Satya Wacana \\ Salatiga, Indonesia \\ $\underline{1682014071 @ \text { student.uksw.edu, }{ }^{2} \text { chris.rudianto@ @ staff.uksw.edu, }{ }^{3} \text { melkior.sitokdana@uksw.edu }}$
}

Diterima: 8 Agustus 2018 | Direvisi: 28 Agustus 2018 | Disetujui: 4 September 2018

\begin{abstract}
Abstrak-Dinas Pariwisata dan Kebudayaan (Disparbud) Kota Ambon adalah suatu instansi pemerintahan yang telah menerapkan TI dalam aktivitas atau proses bisnisnya. Permasalahan yang dihadapi oleh Disparbud Kota Ambon adalah belum diketahui seberapa optimal kinerja sumber daya manusia karena belum dilakukan evaluasi terhadap kinerja sumber daya manusia. Pada penelitian ini menggunakan COBIT 5.0 dengan melakukan pemetaaan tujuan bisnis menggunakan Balanced Scorecard, kemudian pemetaan Enterprise Goals dan IT-Related Goals serta memilih MEA sebagai fokus dari penelitian dengan ketiga subdomain didalamnya yaitu MEA01, MEA02, MEA03. Berdasarkan hasil rekapitulasi data yang didapat pada Disparbud Kota Ambon, maka dapat diukur rata-rata tingkat kapabilitas saat ini adalah 4,56 diukur dari rentang 0-5. Berdasarkan hasil analisis, MEA03 yaitu 4,25 merupakan tingkat kapabilitas tertinggi, dan MEA02 yaitu 3,95 merupakan tingkat kapabilitas terendah. Dengan mengacu pada rata-rata penjumlahan dari MEA01, MEA02, dan MEA03 yang menghasilkan nilai tingkat Capability sebesar 4,06, maka dapat disimpulkan bahwa rata-rata tingkat Capability pada Disparbud Kota Ambon telah mencapai level yang keempat pada tabel Capability Model yaitu mencapai level Predictable Process.
\end{abstract}

Kata kunci-Evaluasi Kinerja, Tata Kelola TI, COBIT .05, Dinas Pariwisata dan Kebudayaan kota Ambon.

\section{PENDAHULUAN}

Perkembangan Teknologi Informasi (TI) sangat pesat dan dapat membawa postitif pada masyarakat termasuk organisasi perusahaan maupun instansi pemerintahan. Pada saat ini ratarata penduduk di dunia telah menikmati hasil dari perkembangan TI yang dapat mendukung proses bisnis secara internal maupun eksternal. Upaya pemanfaatan TI sudah menjadi bagian dari proses bisnis pada suatu instansi yang telah memiliki tujuan dalam mengimplementasikan kegiatan bisnis demi mengembangkan nilai dari instansi tersebut, juga sebagai salah satu cara untuk tetap mempertahankan kepercayaan dan atau kesejahterahan dari kehidupan masyarakat bila dilihat dari segi organisasi pemerintahan. TI saat ini menjadi kebutuhan utama bagi setiap orang pada era globalisasi. Pemahaman akan TI lebih dikhususkan pada orang yang berada pada suatu instansi agar dapat mengoptimalkan kinerja dari suatu instansi tersebut. Pemanfaatan TI bukan hanya dibutuhkan bagi pegawai yang berada pada bidang TI pada suatu instansi saja, akan tetapi menjadi keharusan pada semua bidang dalam instansi tersebut seperti Administrasi, Promosi, dan beberapa bidang lain yang berkaitan dengan $\mathrm{TI}$.

Dinas Pariwisata dan Kebudayaan (Disparbud) Kota Ambon adalah suatu instansi pemerintahan yang telah menerapkan TI dalam aktivitas atau proses bisnisnya. Sangat dikenal bahwa Kota Ambon merupakan kota dengan sejumlah pariwisata dan kebudayaan yang menjadi nilai jual bagi Kota Ambon sendiri. Oleh sebab itu, hal ini menjadi suatu keharusan yang mendasar bagi pemerintah Kota Ambon untuk mengelola potensi alam pada wilayah Kota Ambon dengan memanfaatkan TI sebagai alat untuk mengelola data pemerintahan bagian pariwisata dan kebudayaan secara internal maupun eksternal seperti mempromosikan tempat wisata dan beragam kebudayaan Kota Ambon agar dapat menarik minat wisatawan di dalam maupun luar negeri dengan cara melalui media sosial maupun website Disparbud Kota Ambon tersebut.

Dalam penerapan Teknologi Informasi pada Disparbud Kota Ambon permasalahan yang dihadapi yaitu belum diketahui seberapa optimal kinerja sumber daya manusia karena belum dilakukan evaluasi terhadap kinerja sumber daya manusia. Dalam melakukan evaluasi kinerja TI diperlukan standar atau acuan beberapa diantaranya adalah COBIT, COSO, ITIL, ISO dan lain-lain. Pada penelitian ini standar atau acuan yang akan digunakan adalah menggunakan COBIT 5.0 yang dipilih karena salah satu kerangka bisnis untuk tata kelola dan manajemen perusahaan TI. Penelitian ini hanya terfokus pada salah satu domain didalamnya yaitu Monitor, Evaluate, and Assess (MEA). MEA merupakan suatu domain pada COBIT 5.0 yang tujuannya adalah untuk melakukan pengamatan, mengevaluasi dan menilai semua proses yang berkaitan dengan TI dalam suatu perusahan atau organisasi. Dalam penelitian ini akan digunakan RACI Chart untuk menentukan responden dan untuk mengukur tingkat kematangan TI akan menggunakan Process Capability Model. Hasil penelitian pada Disparbud Kota Ambon yang berfokus 
pada evaluasi Tata Kelola TI diharapkan dapat memberikan rekomendasi untuk membangun dan mengoptimalkan bagian yang terkait dengan penerapan TI pada instansi tersebut di masa yang akan datang.

\section{TINJAUAN PUSTAKA}

\section{A. Penelitian Terdahulu}

Berdasarkan penelitian yang dilakukan oleh Erva Kurniawan (2011), tentang Evaluasi Tata Kelola Teknologi Informasi Dengan Menggunakan Framework COBIT Studi Kasus: Pemerintah Provinsi Daerah Istimewa Yogyakarta (DIY) mengatakan, penyelenggaraan pemerintahan dalam rangka pelayanan publik memerlukan Good Governance, di mana implementasinya akan menjamin transparansi, efisiensi, dan efektivitas penyelenggaraan pemerintahan. Penggunaan teknologi oleh pemerintah DIY memiliki peningkatan dalam memastikan penggunaan TI untuk mendukung tujuan penyelenggaraan pemerintah yang memerlukan Good Governance. Pemerintah DIY telah menjalankan program Jogja Cyber Province (JCP) dan Digital Governance Services (DGS) yang bertujuan untuk memanfaatkan TI dan pengetahuan demi pencapaian target pembangunan wilayah yang dicita-citakan. Namun ada masalah yang terjadi berkaitan dengan masalah pengelolaan data dan informasi serta pengawalan perubahan. Pada penelitian tersebut, peneliti mencoba untuk mengukur dan mengetahui kondisi tata kelola saat ini di pemerintahan DIY. Dan menentukan target yang diharapkan berdasarkan faktorfaktor yang berpengaruh, dengan mendasar kepada model kematangan pada Framework COBIT, sehingga didapatkan kesenjangan tingkat kematangan. Selain hal tersebut, pada penelitian ini dilakukan identifikasi terhadap faktor-faktor yang mempengaruhi pencapaian tingkat kematangan yang diharapkan serta memberi rekomendasi berupa langkah dan tahapan Tata Kelola TI untuk mencapai target tingkat kematangan, untuk memberikan saran kepada Pemerintah Provinsi DIY dalam melakukan pengelolaan TI [1].

Hasil penelitian dari I Nyoman Adi Purbawangsa, Eko Darwiyanto, ST., MT., Kemas Rahmat S. W., ST., M. Eng., (2013), Tentang Evaluasi Sistem E-Government Kota Denpasar Menggunakan Framework COBIT 5 pada Domain Monitor, Evaluate and Assess (MEA) mengatakan, Dinas Kominfo Kota Denpasar sebagai organisasi unsur pelaksana pemerintah yang bertanggung jawab atas pengembangan E-government Pemerintah Kota Denpasar, mengimplementasikan TI untuk mendukung merealisasikan sasaran dan mencapai tujuan melalui pemanfaatan TI yang baik. Manajemen TI di Dinas Kominfo Kota Denpasar memerlukan evaluasi, menilai tingkat kapabilitas dan menyusun rekomendasi terhadap manajemen TI yang belum memenuhi standar. Standar evaluasi yang digunakan adalah COBIT 5 domain Monitor, Evaluate and Assess (MEA) yang berfokus pada pengawasan, penilaian dan kepatuhan regulasi dari keseluruhan sistem TI yang dijalankan oleh Dinas Kominfo Kota Denpasar tetap terjaga dengan baik. COBIT 5 merupakan framework yang memiliki range spektrum proses TI yang luas dan lebih mendetail sehingga sesuai dengan Dinas Kominfo Kota Denpasar yang menggunakan TI yang kompleks dalam pengembangan E-Government. Dari hasil evaluasi, diketahui level kapabilitas dalam area MEA secara keseluruhan berada pada level 1 (Performed) dengan level target yang ingin dicapai adalah level 2 (Managed Process). Kelemahan tata kelola TI di Dinas Kominfo Kota Denpasar adalah kurangnya formalisasi aturan dan prosedur manajemen
TI. Sehingga diberikan rekomendasi untuk dapat mengurangi gap antara level kapabilitas sekarang terhadap target yang ingin dicapai [2].

Menurut penelitian dari S. A. Noya, A. D. Cahyono, dan A. F. Wijaya, "Evaluasi Kinerja Tata Kelola Teknologi Informasi Pada Dinas Perindustrian Dan Tenaga Kerja Kota Salatiga Menggunakan COBIT 5, Pentingnya evaluasi kinerja tata kelola teknologi informasi (TI) adalah untuk menunjang kelancaran proses bisnis dalam organisasi dalam rangka mencapai tujuan organisasi. Dinas Perindustrian dan Tenaga Kerja (Dispernaker) Kota Salatiga merupakan salah satu instansi pemerintah yang terdiri dari bidang perindustrian dan ketenagakerjaan. Salah satu pelayanan yang pada bidang ketenagakerjaan adalah Informasi Pasar Kerja. Dalam rangka menyediakan layanan Informasi Pasar Kerja maka disediakan Sistem Informasi Pasar Kerja (IPK). Pada Penelitian ini standar yang akan digunakan untuk mengevaluasi kinerja TI pada Dispernaker Kota Salatiga adalah menggunakan COBIT 5. Kinerja Sistem IPK menggunakan COBIT 5 pada domain Evaluate, Direct and Monitor (EDM), Align, Plan and Organise (APO), Build, Acquire and Implement (BAI), Deliver, Service and Support (DSS), Monitor, Evaluate and Asses (MEA). Domain proses yang digunakan dalam penelitian didapat dari hasil pemetaan terhadap tujuan bisnis, tujuan TI, dan terkait proses TI. Hasilnya menunjukkan bahwa Sistem IPK telah mencapai level 2 (Manage Process) maupun level 3 (Established Process) [3].

\section{B. Landasan Teori}

1) Teknologi Informasi

Menurut Bodnar dan Hopwood (1995), Teknologi Informasi (TI) merupakan segala cara atau alat yang terintegrasi yang digunakan menjaring, mengolah, dan mengirimkan atau menyajikan data secara elektronik menjadi informasi dalam berbagai format yang bermanfaat bagi pemakainya [4].

Sedangkan Haag dan Keen (1996) mendefinisikan TI sebagai seperangkat alat yang membantu anda untuk bekerja dengan informasi dan melakukan tugas-tugas yang berhubungan dengan pemrosesan informasi. Dalam hal ini TI dianggap alat yang digunakan untuk pekerjaan yang berkaitan dengan informasi [5].

2) Tata Kelola Teknologi Informasi

Tatakelola TI adalah suatu struktur hubungan dan proses untuk mengatur dan mengontrol perusahaan yang bertujuan untuk mencapai tujuan perusahaan yang telah ditetapkan dengan pertambahan nilai dengan tetap menyeimbangkan resiko-resiko dengan nilai yang didapatkan dari penerapan TI dan prosesnya [6]

Teknologi Informasi (TI) merupakan segala cara atau alat yang terintegrasi yang digunakan menjaring, mengolah, dan mengirimkan atau menyajikan data secara elektronik menjadi informasi dalam berbagai format yang bermanfaat bagi pemakainya [4]

\section{3) COBIT 5.0}

Menurut ISACA (2012), COBIT 5.0 adalah salah satu kerangka bisnis untuk tata kelola dan manajemen perusahaan IT. Versi evolusiner ini menggabungkan pemikiran terbaru dalam tata kelola perusahaan dan teknik manajemen, serta menyediakan prinsip-prinsip, praktek, alat-alat analisis dan model yang diterim secara global untuk membantu meningkatkan kepercayaan, dan nilai dari sistem informasi. COBIT 5 membangun dan 
memperluas COBIT 4.1 dengan mengintegrasikan kerangka besar lainnya, standar dan sumber daya, termasuk ISACA Val-IT dan Risiko TI, Technology Infrastructure Library (ITIL®) dan standar yang terkait dari International Organization for Standardization (ISO) [7].

COBIT 5 memiliki 37 proses yang terdapat pada 5 domain yang terbagi dalam 2 domain yaitu Governance dan Management terlihat pada Gambar. 1 [7].

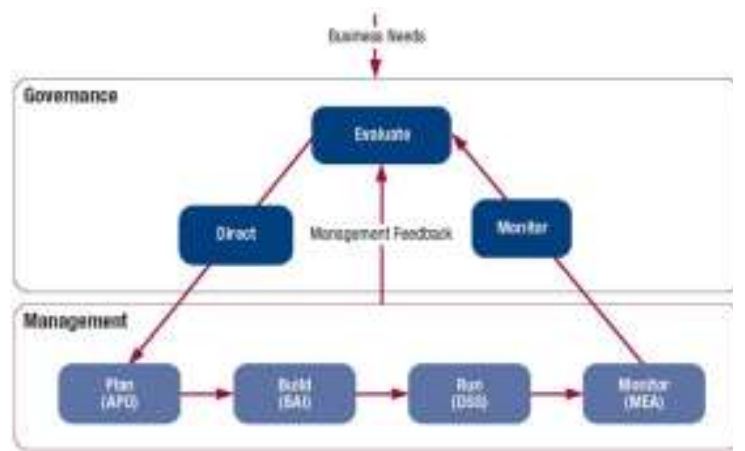

Gambar. 1. COBIT 5.0 Governance and Management Key Areas. (Sumber. ISACA, 2012).

37 proses yang dimiliki COBIT 5 dapat dilihat pada Gambar.2. terlihat dengan jelas masing-masing domain memiliki beberapa proses. Dalam penelitian ini, penulis lebih fokus pada domain Monitor, Evaluate, and Assess (MEA). Domain MEA dapat melakukan pengontrolan atau pengawasan terhadap semua proses yang direncanakan. Semua proses yang berkaitan dengan TI perlu dinilai secara teratur untuk pengontrolan terhadap kualitas dari pengelolaan TI pada perusahaan . Berikut merupakan domain proses MEA:

a) MEA01 Monitor, Evaluate and Assess Performance and Conformance (Pengamatan, Evaluasi dan Menilai Kinerja dan Penyesuaian)

b) MEA02 Monitor, Evaluate and Assess The System of Internal Control (Pengamatan Evaluasi dan Menilai Sistem Pengendalian Internal)

c) MEA03 Monitor, Evaluate and Assess Compliance with External Requirements (Pengamatan, Evaluasi dan Menilai Kepatuhan dengan Persyaratan Eksternal).

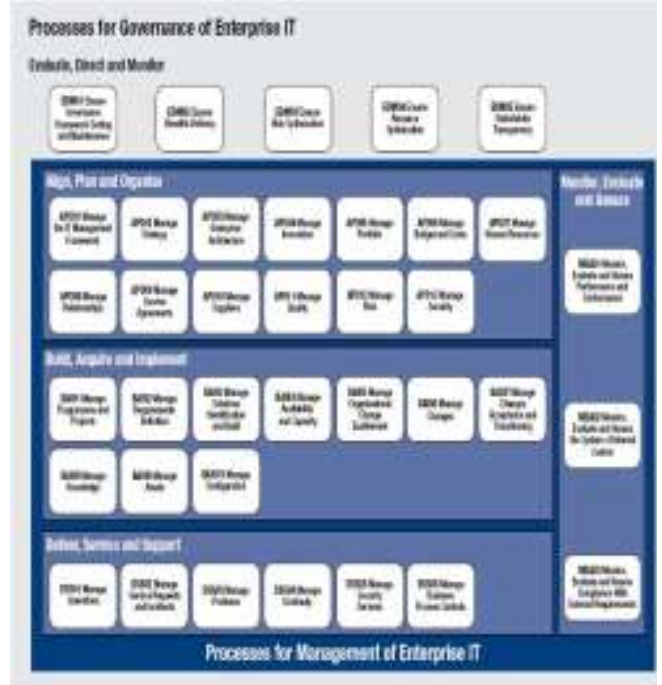

Gambar. 2. Proses COBIT 5.0. (Sumber. ISACA, 2012).

Pada Gambar.3 berikut akan menjelaskan langkah-langkah dalam menentukan domain proses.

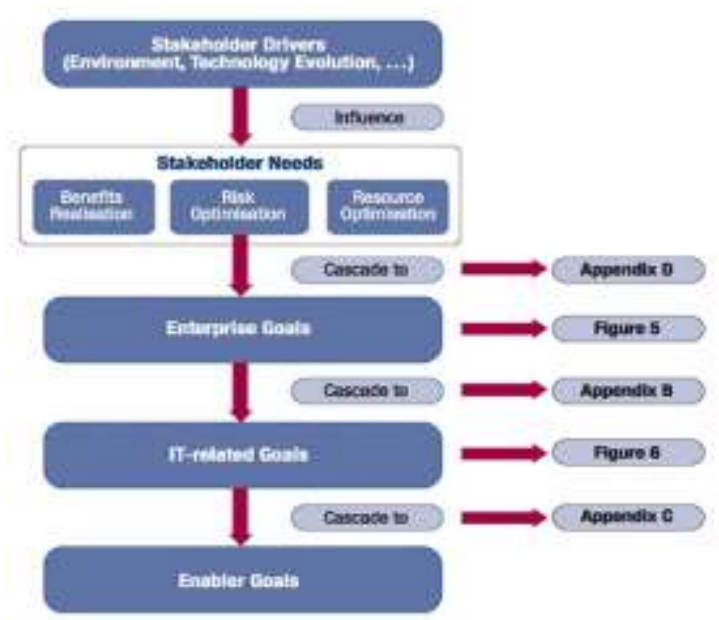

Gambar. 3. COBIT 5.0 Goals Cascade Overview. (Sumber. ISACA, 2012).

COBIT mengelompokkan tujuan-tujuan dalam tujuan bisnis yang terdapat dalam COBIT 5.0, seperti pada Gambar. 4. 


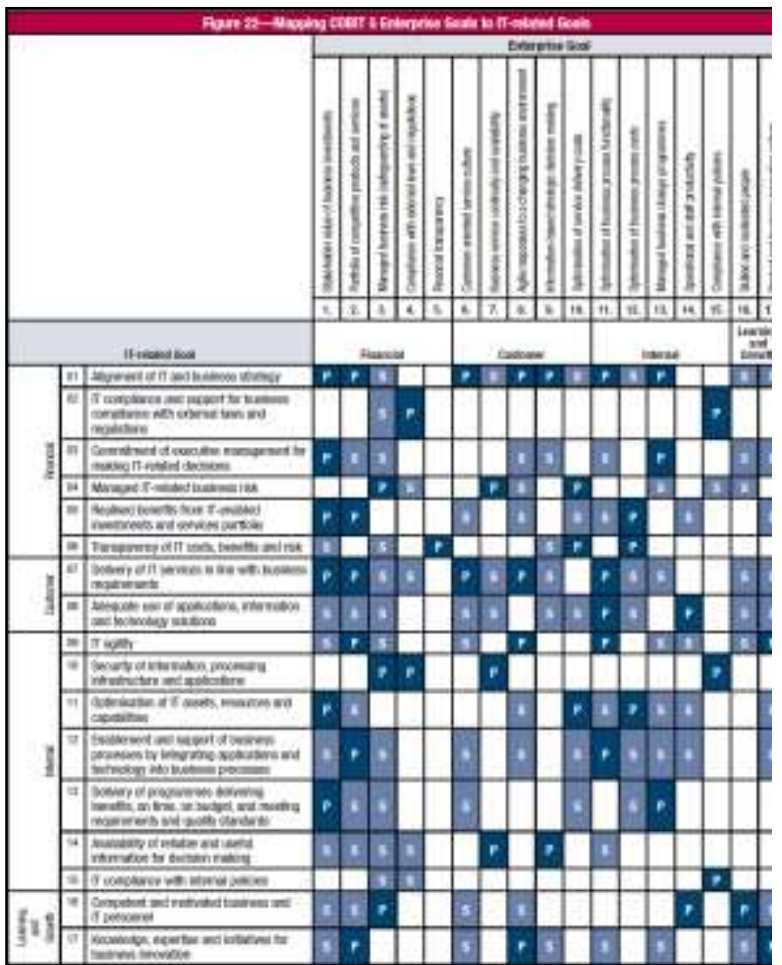

Gambar. 4. Mapping COBIT 5.0 Enterprise Goals to IT-

Related Goals. (Sumber. ISACA, 2012).

Dari Gambar.4 digunakan untuk melakukan pemetaan terhadap tujuan bisnis dan tujuan TI yang terkait. Dari hasil pemetaan tersebut dilanjutkan ke pemetaan dengan Proses TI terkait, terlihat pada Gambar. 5.

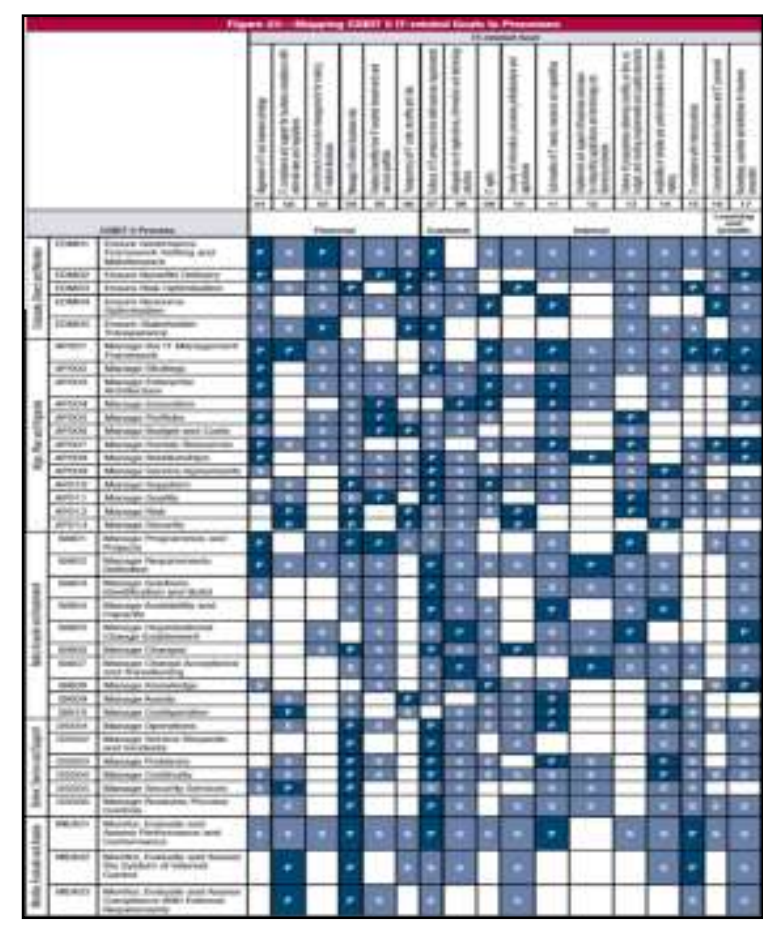

Gambar. 5. Mapping COBIT 5.0 IT-Related Goals to Processes. (Sumber. ISACA, 2012).

Setelah tujuan TI terkait telah diketahui yang memiliki nilai primary $(\mathrm{P})$ kemudian dilakukan pemetaan ke Proses TI.
Maka akan didapat Proses pada COBIT 5.0 yang sesuai dengan tujuan TI untuk dilakukan analisa. Capability Model atau model kapabilitas merupakan suatu model yang dapat mengukur kematangan dan kemampuan dari organisasi perusahaan maupun instansi pemerintahan sesuai dengan kebutuhan dari tiap organisasi perusahaan atau pemerintahan. Dalam kasus ini, Capability Model digunakan untuk mengukur tingkat kematangan dan kemampuan dari Dinas Pariwisata Kota Ambon dalam pemanfaatan TI. Penelitian ini menghasilkan penilaian terhadap dinas terkait dengan fokus pada Domain Monitoring Evaluate and Asses (MEA), dengan 3 sub domain didalamnya yaitu Monitor, Evaluate, and Asses (MEA01), Monitor, Evaluate, and Asses (MEA02), Monitor, Evaluate, and Assess (MEA03). Pada COBIT 5.0 memiliki enam tingkatan kapabilitas yang dapat dicapai oleh masing-masing proses. Keenam tingkatan tersebut dapat dilihat pada Tabel. 1.

Tabel. 1. Tingkatan Kapabilitas. (Sumber. ISACA, 2012).

\begin{tabular}{|c|c|}
\hline Level & Kriteria Ketnatangan \\
\hline o Incomplete Pracess & Proses tidak lengkap \\
\hline 1 Performed Pracess & $\begin{array}{l}\text { Proses dijalankan (satu atribun); Proses yang dimplemertaskan } \\
\text { berhastl mencapai nuivannya }\end{array}$ \\
\hline 2 Managed Pracess & $\begin{array}{l}\text { Proses teratur (dua atribut); Proses yang telah djalankan seperti di } \\
\text { atas telah dirmplementasijan dalam cara yang lebih terahur } \\
\text { (direncanakan. divantan dan disesuajkan) }\end{array}$ \\
\hline 3 Established Pracess & $\begin{array}{l}\text { Proses tetap (dua atribut); Proses di atas telah dimplementaskan } \\
\text { menggunakan proses tertenth yang telah ditetapkan, yzang mampu } \\
\text { mencapai outcome rang dharapkan }\end{array}$ \\
\hline 3 Predictable Pracess & $\begin{array}{l}\text { Proses yang dapat diprediksi (dua atrikun); Proses di atas telah } \\
\text { dfalankan dalam batasan yang dietrikan untuḱ mencapai outcome } \\
\text { proses yang diharapkan }\end{array}$ \\
\hline 5 Optimising Process & $\begin{array}{l}\text { Proses Optinasi (dua atribut); Proses di atas terus dingkatkan secara } \\
\text { berkelarjutan untuk memeeruhi nujuan bistis saat ini dan masa depan }\end{array}$ \\
\hline
\end{tabular}

\section{METODOLOGI PENELITIAN}

\section{A. Tahapan Penelitian}

Metode penelitian yang digunakan adalah Mixed Method atau penelitian campuran antara penelitian kuantitatif dan kualitatif yang respondennya adalah pimpinan dan staf pada Disparbud Kota Ambon. Tahapan penelitian dapat dilihat pada Gambar. 6. Mohon diperhatikan beberapa hal berikut ini dalam penulisan:

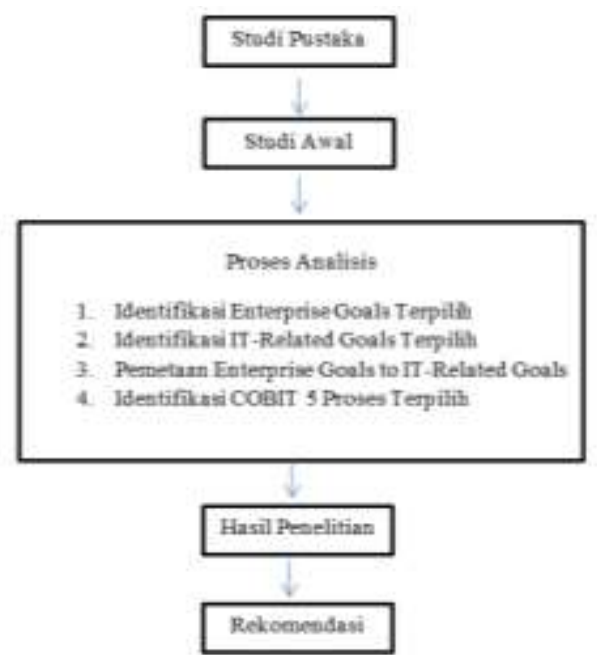

Gambar. 6. Tahapan Penelitian. 
Tahapan pertama adalah Studi pustaka yang dilakukan dengan mempelajari pengetahuan tentang COBIT 5.0.

Tahapan kedua adalah Studi Awal yang dilakukan dengan cara mengobservasi objek penelitian untuk mendapatkan data secara langsung melalui hasil pengamatan, wawancara yang dilakukan melalui tanya jawab pada responden, dan melalui kuesioner yang merupakan alat pendukung bagi peneliti untuk mengamati suatu peristiwa melalui serangkaian pertanyaan tertulis yang diedarkan kepada sejumlah responden pada Disparbud Kota Ambon.

Tahapan ketiga adalah Proses Analisis, tahapan ini dilakukan melalui empat proses yaitu mengidentifikasi Enterprise Goals terpilh, mengidentifikasi IT-Related Goals terpilih, Pemetaan Enterprise Goals to IT-Related Goals, Mengidentifikasi COBIT 5.0 Proses Terpilih (Fokus domain MEA).

Tahapan keempat adalah Hasil Penelitian dilakukan dengan analisis hasil perhitungan rata-rata sub proses dari masingmasing sub domain MEA, Rata-rata proses dari masing-masing sub domain MEA, merepresentasikan hasil dari pengukuran tingkat Capability.

Tahapan kelima adalah rekomendasi yang diberikan kepada objek penelitian untuk mengoptimalkan kinerja TI dimasa yang akan datang.

\section{B. Responden Penelitian}

Untuk mengambil sampel dari populasi yang ada pada Disparbud Kota Ambon, maka digunakan model RACI (Responsibility, Accountability, Consult, and Informed) untuk mengetahui tingkat kapabilitas [7]. Sesuai dengan hasil analisa dan pengamatan tentang struktur organisasi dengan tugas dan tanggung jawab dari tiap pegawai pada instansi yang bersangkutan, maka penulis dapat mengambil sampel dari 8 responden yang merupakan beberapa pegawai yang mengelola TI dalam Dinas dan beberapa kepala sub bagian sebagai atasan dari pengelola TI, termasuk Kepala Dinas sebagai orang yang bertanggung jawab dalam Satuan Kerja Perangkat Daerah (SKPD). Dengan tujuan mempermudah kebutuhan penulis terhadap pengambilan data sesuai dengan tugas pokok dan fungsi (Tupoksi) pada masing-masing pejabat dan staf pada Disparbud Kota Ambon, maka dibutuhkan RACI Models yang fungsinya untuk menggambarkan RACI Roles ke Organitation Roles. Hasil analisa dapat dijelaskan dalam Tabel. 2.

Tabel. 2. Pemetaan RACI Chart Disparbud Kota Ambon.

\begin{tabular}{|c|c|c|}
\hline No & RACIROLES & ORGANTATION ROLES \\
\hline 1 & CEO (Chief Executive Officer) & Selaretaris Dinas Pz. Kepala Dinas \\
\hline 2 & CFO (Chicf Finecial Officer) & KASUBAG Keusengan \\
\hline 3 & Head II Adminietratisn & Seluetaris Dinas Py. Kepala Dinas \\
\hline 4 & Finance Officer & Staf Pembuar Lavoran Keusenan \\
\hline 5 & Strategy Erecurive Officer & KASLBAG Pereacanaan \\
\hline 6 & Serategy Evecistive & KASI Petescanaan \\
\hline 7 & Chief Operating Office & Staf Pengadmiriserasi Kepegawaían \\
\hline
\end{tabular}

\section{HASIL DAN PEMBAHASAN}

\section{A. Identifikasi Enterprise Goals Terpilih}

Pada tahap ini tujuan dari Disparbud Kota Ambon diselaraskan dengan Enterprise Goals pada COBIT 5.0. Hasil dari tujuan Disparbud Kota Ambon yang tertera pada tabel didapat dari menganalisis kebutuhan stakeholder yang memiliki prioritas tinggi dan berkaitan dengan Disparbud Kota Ambon, kemudian dianalisis dengan Balanced Scorecard yang didalamnya memiliki empat perspektif yaitu Financial, Customer, Internal dan Learning \& Growth sehingga dapat memberikan hasil pengukuran yang lengkap. Hasil pengukuran tersebut diselaraskan kembali dengan Enterprise Goals dalam COBIT 5.0 dengan cara melakukan identifikasi terhadap adanya keterhubungan antara tujuan Disparbud Kota Ambon dengan Enterprise Goals COBIT 5.0. Keterhubungan tersebut dapa dijelaskan pada Tabel. 3 .

Tabel 3. Analisis Keterhubungan Antara Tujuan Disparbud Kota Ambon dan COBIT 5.0.

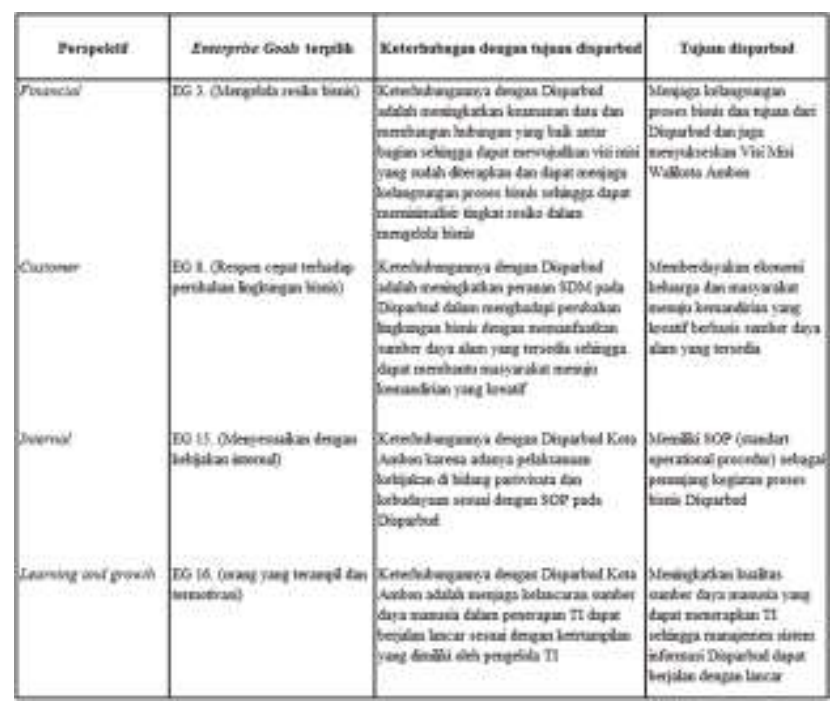

\section{B. Identifikasi IT-Related Goals Terpilih}

Berdasarkan Enterprise Goals terpilih, dapat menentukan IT-Related Goals menggunakan tabel Mapping COBIT 5.0 Enterprise Goals to IT-Related Goals. Hasil pemetaan tersebut dapat dilihat pada Tabel. 4.

Tabel. 4. IT-Related Goals Ternilih

\begin{tabular}{|c|c|c|c|}
\hline \multirow{2}{*}{ No } & \multirow{2}{*}{ Kode Enterprise Goal Terpilih } & \multicolumn{2}{|c|}{ Mapping Enterprise Goals To It Related Goa } \\
\hline & & Ada Keterhubungan & It Related Goals \\
\hline 1 & $E G_{3}$ & $\sqrt{2}$ & $4,10,16$ \\
\hline 2 & EGB & $\sqrt{ }$ & 1. $7,9,17$ \\
\hline 3 & EG15 & $\sqrt{ }$ & $2,10,15$ \\
\hline 4 & EG16 & $\sqrt{ }$ & 16 \\
\hline
\end{tabular}

\section{Pemetaan Enterprise Goals to IT-Related Goals}

Melalui pemetaan Enterprise Goals to IT-Related Goals, kemudian digunakan Process Capability Model (PCM) yang didalamnya terbagi menjadi dua kategori yaitu primary $(\mathrm{P})$ yang menunjukan bahwa adanya keterhubungan yang tinggi antara Enterprise Goals to IT-Related Goals, dan secondary (S) menunjukan bahwa adanya keterhubungan yang rendah antara Enterprise Goals to IT-Related Goals. Hasil dari pemetaan tersebut dapat dilihat pada Gambar. 7. 


\begin{tabular}{|c|c|c|c|c|}
\hline & EG 3 & EG 8 & EG 15 & EG 16 \\
\hline IT - G 1 & $\mathrm{~s}$ & $\mathrm{P}$ & & $\mathrm{S}$ \\
\hline II - G 2 & s & & P & \\
\hline $\mathrm{IT} \cdot \mathrm{G} 3$ & $\mathrm{~s}$ & S & & S \\
\hline $\mathrm{II}-\mathrm{G} 4$ & $\mathrm{P}$ & $\mathrm{s}$ & s & $s$ \\
\hline II - G 5 & & $\mathrm{~S}$ & & \\
\hline II - G 6 & s & & & \\
\hline II-G? & $\mathrm{s}$ & P & & s \\
\hline IT - G 8 & $\mathrm{~s}$ & & & $\mathrm{~S}$ \\
\hline II-G 9 & $\mathrm{~s}$ & $\mathrm{P}$ & & $\mathrm{S}$ \\
\hline IT - G 10 & P & & P & \\
\hline IT - G 11 & & $\mathrm{~s}$ & & \\
\hline IT - G 12 & S & $\mathrm{s}$ & & \\
\hline IT - G 13 & $S$ & & & \\
\hline II - G 14 & $\mathrm{~s}$ & & & \\
\hline IT - G 15 & s & & $\mathrm{P}$ & \\
\hline II - G 16 & P. & S & & $\mathrm{P}$ \\
\hline $\mathrm{IT} \cdot \mathrm{G} 17$ & & P & & $\mathrm{s}$ \\
\hline
\end{tabular}

Gambar. 7. Pemetaan Enterprise Goals to IT-Related Goals.

\section{Identifikasi COBIT 5.0 Proses Terpilih}

Setelah pemetaan Enterprise Goals to IT-Related Goals, langkah berikutnya adalah menentukan COBIT 5.0 IT-Related Goals terpilih yang ditentukan berdasarkan tabel IT-Related Goals terpilih. Pemetaan tersebut dapat dilihat pada Tabel. 5.

Tabel. 5. COBIT 5 Proses Terpilih Sesuai IT-Related Goals.

\begin{tabular}{|c|c|l|}
\hline No & Kode $I T$ - Related Goals & $\begin{array}{c}\text { COBIT 5.0 Process } \\
\text { (MIE.A01, MEA02, MEA03) }\end{array}$ \\
\hline 1 & IT - G 2 & ME.A02, MEA03 \\
2 & IT - G 4 & ME.A01, ME.A02, MEA03 \\
3 & IT - G 7 & MEA01 \\
4 & IT - G 15 & MEA01, MEA02 \\
\hline
\end{tabular}

\section{E. Hasil Penelitian}

Hasil dari pengukuran kapabilitas dan penerapan Framework COBIT 5.0 pada Disparbud Kota Ambon yang fokus pada Domain MEA di gambarkan dalam bentuk grafik dan tabel. Ini merupakan tujuan sehingga dapat mempermudah proses analisis dan memperkirakan kebutuhan instansi terkait dengan TI, khususnya pada tata kelola dinas terkait.

Dalam hasil analisa data pada Disparbud Kota Ambon, penulis dapat menyimpulkan menurut hasil observasi, wawancara dan hasil pengumpulan data kuesioner pada instansi tersebut bahwa sejauh mana tingkat kapabilitas yang telah memenuhi pencapaian target pada level tertentu yang telah ditetapkan oleh kerangka kerja COBIT 5.0. Dengan pengukuran dari hasil analisis yang dilakukan dapat membuktikan bahwa Tata Kelola pada dinas terkait telah memanfaatkan TI dalam kepentingan berorganisasi.

Dalam penelitian ini menggunakan COBIT 5.0 khususnya pada domain MEA sebagai acuan pertanyaan untuk menggali informasi pada dinas terkait. MEA memiliki 3 Sub Domain dengan fungsi yang berbeda yaitu:

a) Monitor, Evaluate, and Asses (MEA01)

Pengawasan, evaluasi penilaian kinerja proses TI pada Disparbud Kota Ambon terhadap kebijakan yang telah ditetapkan dan memberikan laporan yang sistematis dan tepat waktu kepada Kepala Dinas sebagai pemimpin SKPD. b) Monitor, Evaluate, and Asses (MEA02)

Pengawasan, evaluasi dan penilaian sistem pengendalian internal, termasuk dalam merencanakan, mengatur dan menjaga standarisasi untuk penilaian pengendalian internal dan jaminan proses kegiatan, dalam dalam hal ini menyediakan program pelatihan mengenai pemanfaatan TI dan komunikasi kepada pengguna sistem. Pada proses ini terdiri dari 8 pertanyaan.

c) Monitor, Evaluate, and Asses (MEA03)

Pengawasan, evaluasi dan penilaian sistem pengendalian eksternal yaitu mengidentifikasi dan memonitor perubahan dalam kebijakan, peraturan dan ketetapan lainnya yang harus dipenuhi dari TI secara terus menerus. Pada proses ini terdiri dari 4 pertanyaan.

Sesuai dengan hasil rekaapitulasi data yang didapat dari hasil penelitian pada Disparbud Kota Ambon, maka dapat diukur rata-rata tingkat kapabilitas saat ini adalah 4,56 diukur dari rentang 0-5 berdasarkan kriteria kematangan yang ditetapkan oleh COBIT 5.0. Nilai rata-rata diukur berdasarkan rata-rata penjumlahan dari MEA01, MEA02, MEA03 dan dibagi 3 (menurut 3 sub domain pada MEA). Berdasarkan hasil pengolahan data dari responden, MEA03 yaitu 4,25 merupakan tingkat kapabilitas tertinggi, dan MEA02 yaitu 3,95 merupakan tingkat kapabilitas terendah. Selanjutnya dapat dilihat pada Tabel. 6 .

Tabel. 6. Hasil Rekapitulasi Hasil Penelitian dan Nilai RataRata berdasarkan Hasil Penjumlahan Rata-Rata Antara MEA01, MEA02, MEA03.

\begin{tabular}{|c|c|c|c|c|}
\hline Domain & Proses & $\begin{array}{c}\text { Rata-rata } \\
\text { Responden }\end{array}$ & $\begin{array}{l}\text { Rata-Rata } \\
\text { SubProses }\end{array}$ & $\begin{array}{c}\text { Rata-Rata } \\
\text { Proses }\end{array}$ \\
\hline MEA01 & $\begin{array}{l}\text { MEA } 01.01 \\
\text { MEA01.02 } \\
\text { MEA01.03 } \\
\text { MEA01.04 } \\
\text { MEA01.05 }\end{array}$ & $\begin{array}{c}4,43 \\
3,71 \\
4,29 \\
4 \\
3,43\end{array}$ & 19,86 & 3,97 \\
\hline MIEA02 & $\begin{array}{l}\text { MEEA02.01 } \\
\text { MEA } A 02.02 \\
\text { MEA02.03 } \\
\text { MEEA02.04 } \\
\text { MEA02.05 } \\
\text { AEA } A 02.06 \\
\text { MEA } 02.07 \\
\text { MEA } 02.08\end{array}$ & $\begin{array}{c}4,57 \\
4 \\
4,14 \\
3,86 \\
3,71 \\
3,71 \\
3,86 \\
3,71\end{array}$ & 31,57 & 3,95 \\
\hline MIEA03 & $\begin{array}{l}\text { MEA03.01 } \\
\text { MEA } 03.02 \\
\text { MEA } 03.03 \\
\text { MEA } 03.04 \\
\end{array}$ & $\begin{array}{c}4,14 \\
4,43 \\
4,43 \\
4 \\
\end{array}$ & 17 & 4,25 \\
\hline \multicolumn{3}{|c|}{ Jamlah } & 68,43 & 12,17 \\
\hline \multicolumn{3}{|c|}{ Nilai Rata-Rata Subproses } & Nilai Tiagkat Copability & 4,06 \\
\hline
\end{tabular}

\section{F. Pembahasan}

Untuk mendukung proses analisa data yang didapat melalui kuesioner tersebut, maka diperlukan beberapa tahap yaitu:

a) Menghitung rata-rata sub proses dari masing-masing sub domain MEA

b) Menghitung rata-rata proses dari masing-masing sub domain MEA

c) Merepresentasikan hasil dari pengukuran tingkat Capability. 
Dalam perhitungan tersebut juga menggunakan rumus sebagai berikut:

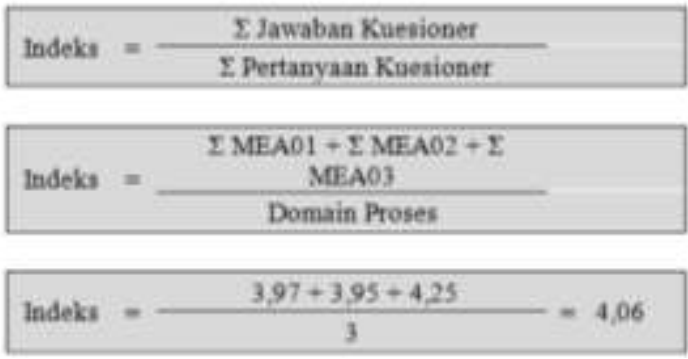

Skala pembuatan indeks pada tingkat model Capability dapat dilihat pada Gambar. 8.

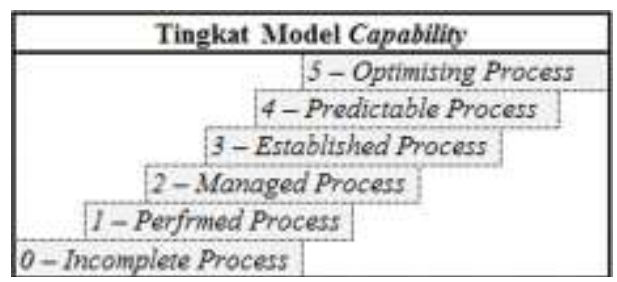

Gambar. 8. Tingkat Model Kapabilitas.

Hasil pengukuran Tingkat Capability dapat dilihat pada Tabel. 7.

Tabel. 7. Hasil Pengukuran Tingkat Kapabilitas.

\begin{tabular}{|c|c|c|}
\hline \multirow{2}{*}{$\begin{array}{c}\text { DOMAIN } \\
\text { MEA/PROSES TI }\end{array}$} & Kondisi TI Saat ini & \multirow{2}{*}{$\begin{array}{c}\text { Tingkat Model } \\
\text { Capability }\end{array}$} \\
\hline & $\begin{array}{c}\text { Rata-Rata Per Proses } \\
\text { TI }\end{array}$ & \\
\hline $\begin{array}{l}\text { Evaluasi dan penilaian } \\
\text { kinerja dan kesesuaian } \\
\text { (MEAOI) }\end{array}$ & 3,97 & Predictable Pracess \\
\hline $\begin{array}{l}\text { Pengawasan, evaluasi } \\
\text { dan penilaian sistem } \\
\text { pengendalian intemal } \\
(\mathrm{ME} 402) \\
\text { Memastikan }\end{array}$ & 3,95 & Predictable Process \\
\hline $\begin{array}{l}\text { pemenuhan terbadap } \\
\text { kebutuhan } \\
\text { a eksternal } \\
\end{array}$ & 4,25 & Predictable Procesu \\
\hline $\begin{array}{c}\text { Total Nilai Tingkat } \\
\text { Capability }\end{array}$ & 4,06 & Predictable Process \\
\hline
\end{tabular}

Jika hasil dari pengukuran Capability dari Disparbud Kota Ambon di gambarkan dalam bentuk grafik maka dapat dilihat pada Grafik. 1.

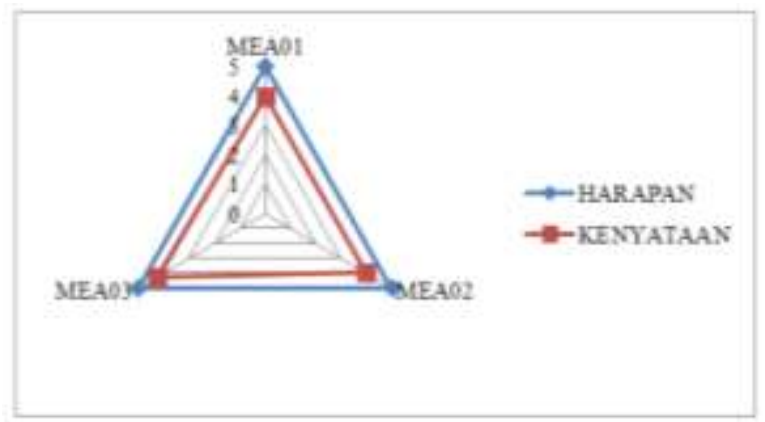

Grafik. 1. Hasil Pengukuran Kapabilitas Dalam Bentuk Grafik.
Untuk menganalisis kesenjangan juga bertujuan untuk mengetahui tingkat GAP pada Disparbud Kota Ambon, maka dapat dihitung dengan Kenyataan dikurangi Harapan. Proses pengukuran GAP dapat dilihat pada Grafik 2, 3 dan 4.

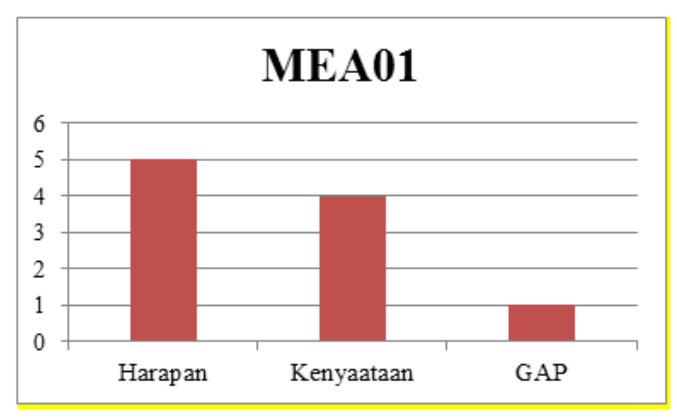

Grafik. 2. Hasil Analisa Kesenjangan MEA01.

Pada Grafik. 2 dapat disimpulkan bahwa kenyataan saat ini mencapai angka 3,97 dengan GAP 1,03. Dengan demikian pada Evaluasi dan penilaian kinerja dan kesesuaian (MEA01) memiliki tingkat Capability mencapai pada level Predictable Process.

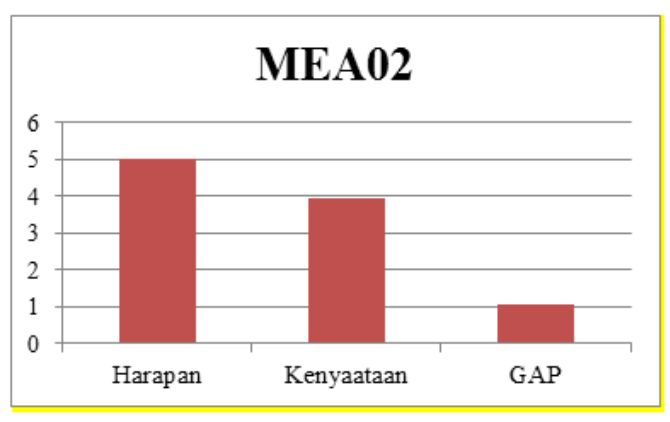

Grafik. 3. Hasil Analisa Kesenjangan MEA02.

Pada Grafik. 3 dapat disimpulkan bahwa kenyataan saat ini mencapai angka 3,95 dengan GAP 1,05. Dengan demikian pada Pengawasan, evaluasi dan penilaian sistem pengendalian internal (MEA02) memiliki tingkat Capability mencapai pada level Predictable Process.

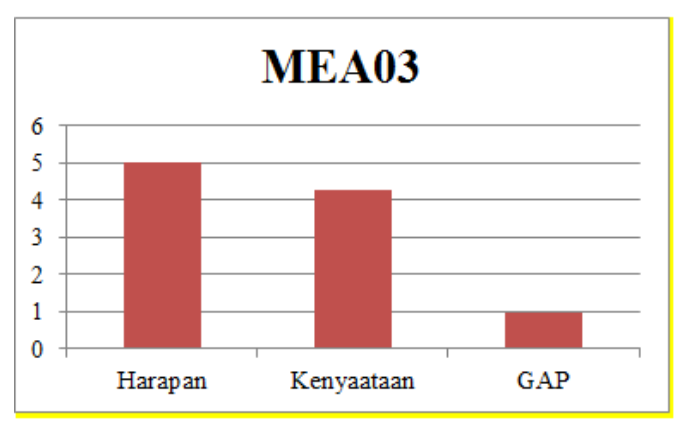

Grafik. 4. Hasil Analisa Kesenjangan MEA03.

Pada Grafik. 4 dapat disimpulkan bahwa kenyataan saat ini mencapai angka 4,25 dengan GAP 0,94. Dengan demikian pada Monitoring Evaluate and Asses 03 yang membahas mengenai memastikan pemenuhan terhadap kebutuhan eksternal memiliki tingkat Capability mencapai pada level Predictable Process. 


\section{KESIMPULAN DAN REKOMENDASI}

\section{A. Kesimpulan}

Berdasarkan hasil penelitian yang dilakukan pada Disparbud Kota Ambon, maka dapat disimpulkan bahwa ratarata tingkat Capability pada Disparbud Kota Ambon telah mencapai level yang keempat pada tabel Capability Model yaitu mencapai Predictable Process yang berarti Proses pada domain MEA01, MEA02, MEA03 telah dijalankan dalam batasan yang ditentukan untuk mencapai outcome process yang diharapkan dengan total nilai pada tingkat Capability adalah 4,06. Proses yang memiliki nilai tertinggi adalah pada domain MEA02 dengan proses pertama yaitu telah melakukan pemantauan yang baik, serta telah meningkatkan pengendalian TI dan melakukan pengontrolan terhadap kerangka kerja untuk memenuhi tujuan dari instansi. Akan tetapi Disparbud Kota Ambon harus tetap menjalankan tata kelola TI dan meningkatkan kinerja pada sumber daya manusia untuk mencapai target yang telah diharapkan dalam jangka waktu yang telah ditentukan sesuai dengan tujuan organisasi saat ini maupun pada masa depan organisasi.

\section{B. Rekomendasi}

Rekomendasi yang diusulkan untuk perbaikan bagi Disparbud Kota Ambon dalam menengani permasalahan dan untuk mengoptimalkan kinerja pegawai adalah sebagai berikut:

a) Menerapkan Framework COBIT untuk mengoptimalkan kinerja sumber daya manusia dalam mengatur Tata Kelola TI yang lebih baik dari saat ini.

b) Diperlukan Tim Audit internal khususnya pada Tata Kelola TI dalam Disparbud Kota Ambon untuk memonitoring, mengevaluasi dan menganalisis Tata Kelola TI dalam tiap periode sesuai keputusan oleh Disparbud Kota Ambon.

c) Pengawasan dari Kepala Dinas terhadap Tata Kelola TI pada Disparbud Kota Ambon terkait dengan pelaksanaan tindakan perbaikan untuk tindakan yang tidak sesuai dengan tujuan instansi.

d) Meningkatkan ketrampilan khusus kepada sumber daya manusia serta melakukan jaminan dalam menjalankan tugas sesuai dengan standar operasional, dan memiliki inisiatif untuk memberikan rekomendasi perbaikan yang berkaitan dengan kinerja operasional, kepatuhan, dan pengendalian resiko.

\section{Referensi}

[1] E. Kurniawan, "Evaluasi Tata Kelola Teknologi Informasi Dengan Menggunakan Framework Cobit Studi Kasus: Pemerintah Provinsi Daerah Istimewa Yogyakarta," Tesis, Universitas Gadjah Mada, Yogyakarta, 2011.

[2] I. N. Purbawangsa, "EvaluasiSistem E-Government Kota Denpasar Menggunakan Framework COBIT 5 pada Domain Monitor, Evaluate and Assess (MEA)," hlm. 1-9, 2014.

[3] S. A. Noya, A. D. Cahyono, dan A. F. Wijaya, "Evaluasi Kinerja Tata Kelola Teknologi Informasi Pada Dinas Perindustrian Dan Tenaga Kerja Kota Salatiga Menggunakan Cobit 5," vol. 3, hlm. 14, 2018.
[4] Bodnar, George H dan Hopwood, William S., "Accounting information systems / George H. Bodnar, William S. Hopwood. - Version details," Trove. [Daring]. Tersedia pada: https://trove.nla.gov.au/version/46660604. [Diakses: 18-Jul-2018].

[5] S. Haag, Information Technology: Tomorrow's Advantage Today. McGraw-Hill Companies, Inc., P.O. Box 545, Blacklick, OH 43004, Attn: Order Service (\$33 text with, 1996.

[6] IT Governance Institute, Board briefing on IT governance. Rolling Meadows, Ill.: IT Governance Institute, 2003.

[7] Information Systems Audit and Control Association, Ed., COBIT 5: a business framework for the governance and management of Enterprise IT: an ISACA ${ }^{\circledR}$ framework. Rolling Meadows, Ill: ISACA, 2012. 